高速繰り返しQスイッチ発振YAGレーザーにおける

1パルス加工量と加工音の相関性の研究

栗田 恒雄, 大野 幸彦*, 森田 昇**

東京都立科学技術大学大学院 (テ191-0065 東京都日野市旭が丘6-6)

*東京都立科学技術大学 工学部機械システム工学科 (テ191-0065 東京都日野市旭が丘6-6)

**千葉大学 工学部機械工学科 (テ263-8522 千葉市稲毛区弥生町1-33)

\title{
Study of the Relationship between Groove Cross-Sectional Area per Pulse of High Repetition Q-switched YAG Laser and Strength of Processing Sound
}

\author{
Tsuneo KURITA, Tomohiko ONO*, and Noboru MORITA** \\ Graduate school, Tokyo Metropolitan Institute of Technology, 6-6 Asahigaoka, Hino, Tokyo 191-0065 \\ *Department of Mechanical Systems Engineering, Faculty of Engineering, Tokyo Metropolitan Institute of Technology \\ 6-6 Asahigaoka, Hino, Tokyo 191-0065 \\ **Department of Mechanical Engineering, Faculty of Engineering, Chiba University, \\ 1-33 Yayoi-cho, Inage-ku,Chiba 263-8522
}

(Received October 14, 1998)

\begin{abstract}
The goal of the research is to construct a laser processing system for the manufacture of stepped shapes. In order to achieve this goal, this study aims to clarify the relationship between the strength of laser processing sound and groove cross-sectional area per pulse when a Q-switched YAG laser beam was applied for laser grooving. The main findings of this study are as follows: 1) The relationship between the strength of the processing sound and groove cross-sectional area per pulse of Q-switched laser beam could be expressed by a straight line on a log-log chart even if the applied laser energies were changed, and 2) The gradient of the straight line showed different values when two types of work materials were processed by a Q-switched YAG laser.
\end{abstract}

Key Words: Q-switched YAG laser, Ceramic material, Groove cross-sectional area, Processing sound, Monitoring

\section{1. 緒 論}

工具と被加工材料の接触によって加工が行われる機械 加工とは異なり,レーザー加工はエネルギーを直接被加工 材料に加えて材料の除去等を行うために, 加工特性が材料 の硬さに依存しないこと,また材料表面に照射されるレー ザー光の焦点径は理論的にはレーザー光の波長と同じ值 にまで小さくすることができるので非常に精密な加工を 行うことが可能であるなどの特徴を備えている。しかし， レーザー加工ではこれらの長所を利用して加工すること が可能な反面, 加工工具が存在しないために除去される量 あるいは加工される深さをほぼ一定に保つことが困難で あるし, 更に溶融, 蒸発などの現象が連続的に発生するた めに, 加工特性をモニタリングすることが極めて困難であ るなどの問題をもっている。これらのことから,レーザー 加工における利点を十分に活用するために, 加工状態を監 視し, 特定の情報を用いて加工特性を制御できるレーザー 加工システムを開発することができれば, レーザー加工の
高度化に資することができると考える。これを達成する ために, 加工の情報として加工中に発生する加工音を用い ることが試みられている1-10). 本研究の最終目標はレー ザー加工時に発生する加工音を用いて加工状態を監視し， 制御を行うレーザー溝加工を対象とした加工システムを 開発することである. 加工条件を変化させて加工特性の 制御を行う場合, 種々の加工条件を複雑かつ緻密に変化さ せる必要がある。この制御中に発生した加工音を用いて 加工状態の監視を行うためには, 加工条件の変化に対して 影響を受けない基本的な加工音と加工特性との関係を求 めることが重要である．筆者らは, 加工音と加工特性の関 係としてYAGレーザー光1パルスを照射したときに増加す る加工穴の断面積とそのときの加工音の関係に注目し, 照 射周波数1Hzの低速繰り返しQスイッチ発振YAGレーザー による穴あけ加工を行い, 1パルス当たりの加工穴断面積と 加工音に含まれる特定の周波数の音圧レベルとの関係を 求め, 両者の間にはある幅を持つ直線関係が存在すること を実験的に明らかにした11).しかしレーザー光1パルスに 
よる加工穴断面積の変化は少なく,それに依存する加工穴 断面積の測定誤差などのために,両者の関係をある幅を持 つ直線関係としてしか表わすことができなかった。この 関係が正確に表現でき,かつ様々な加工条件との関係が明 らかにな机ば, 低速繰り返しQスイッチ発振YAGレーザー 1パルス照射時の加工音と加工特性との関係から,レーザー 光1パルス照射の連続が溝加工であると考えて,レーザー溝 加工時の加工特性を加工音から監視することが可能にな ると考える。本研究は, 1 パルスのYAGレーザー光で除去 される加工溝断面積の大きさと加工音の強さとのより正 確な関係を, 高速繰り返しQスイッチ発振YAGレーザーを 用いた様々な加工条件に扔ける溝加工の結果を用いて明 らかにすること,およびこの関係におよぼす被加工材料の 影響をセラミック系材料を対象として実験的に明らかに することを目的としている。

\section{2. 実験装置}

Fig.1にレーザー加工時に発生する加工音を検出および 分析するために用いた実験装置の構成を示す。レーザー 発振器は, 連続励起のTEM ${ }_{00}$ シングルモードYAGレーザー 光を発振する装置に, AO-Qスイッチが付加しているLAY615型である。な㧍本論文では, 付属しているQスイッチに よって照射周波数を $500 \mathrm{~Hz} \sim 50 \mathrm{kHz}$ の範囲で変化させる高 速繰り返しQスイッチ発振動作によるレーザー光を, $\mathrm{Q}$ ス イッチ発振YAGレーザーと記述する。

数值制御ステージにセットした被加工材料にQスイッチ 発振YAGレーザーを照射し, 発生した加工音はレーザー光 照射点から $40 \mathrm{~mm}$ の距離で, 被加工材料の表面に対して 30deg傾けて設置したコンデンサマイクロフォンで集音し てから騒音計を用いて増幅し, DAT(Digital Audio Tape)レ コーダに収録した，収録した加工音はFFT解析装置を用い て,加工音強さの時間に対する変化を計測した。なお,加工 音の強さと対比させる加工溝断面積は,被加工材料の断面を \#1000のダイヤモンド研削砥石によって形成し,走査型電子 顕微鏡 (SEM) 像を用いて測定した溝断面積で表現した.

\section{3. 実験結果}

3.1 加工音強さの測定

Fig.2に, 被加工材料として $\left(\mathrm{Al}_{2} \mathrm{O}_{3}+\mathrm{TiC}\right)$ ヒラミックを選

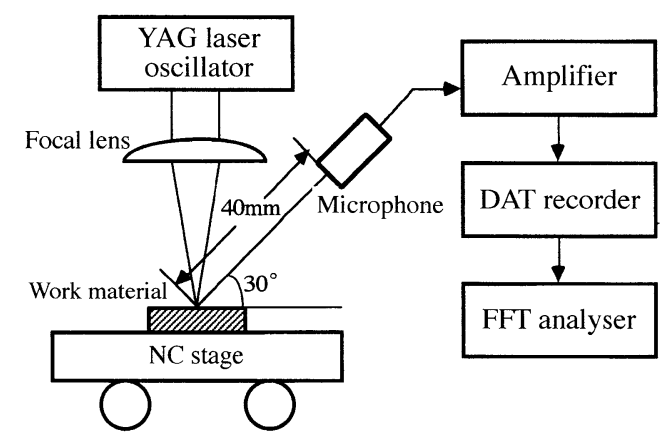

Fig.1 Experimental setup for a detection and an analysis of laser processing sound.

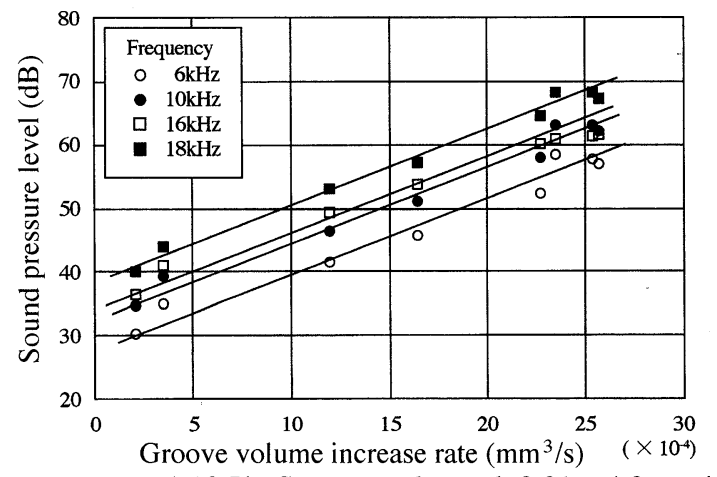

Laser energy: $1.10 \mathrm{~J} / \mathrm{s}$, Stage travel speed: $0.01 \sim 4.0 \mathrm{~mm} / \mathrm{s}$,

Q-sw. frequency: $2 \mathrm{kHz}$, Work material: $\mathrm{Al}_{2} \mathrm{O}_{3}+\mathrm{TiC}$

Fig.2 Relationship between groove volume increase rate and sound pressure level.

定し, Qスイッチ周波数 $2 \mathrm{kHz}$ 扩よびレーザーエネルギー $1.10 \mathrm{~J} / \mathrm{s}$ の条件でステージ移動速度を $0.01 \sim 4.0 \mathrm{~mm} / \mathrm{s}$ に変化 させて溝加工を行った時に発生した加工音を周波数分析 し, 設定したQスイッチ周波数の整数倍の周波数における 音圧レベルと加工量の関係を示す。同図には4 種類の周波 数に扔ける音圧レベルと単位時間当たりの除去体積(加工 溝体積増加速度) との関係を示しているが,いずれの周波数 の場合とも, 加工溝体積増加速度と音圧レベルの関係は直 線で表すことができる。このことは加工音と加工溝体積 増加速度の関係を表現するのに, 特定の周波数に打ける音 圧レベルを用いなくてもよいことを示している12)。そこ で本報では, 加工中に発生する加工音の代表值として加工 音の強さを用いる方法を試みた. Fig.3は,被加工材料とし て $\left(\mathrm{Al}_{2} \mathrm{O}_{3}+\mathrm{TiC}\right)$ セラミックおよび $(\mathrm{WC}+\mathrm{Co})$ 超硬合金を 選定し, ステージ移動速度 $1 \mathrm{~mm} / \mathrm{s}, \mathrm{Q}$ スイッチ周波数 $3 \mathrm{kHz}$ 抢 よびレーザーエネルギー $1.40 \mathrm{~J} / \mathrm{s} の$ 条件で溝加工を行った 時に発生した, 加工音強さの加工時間に対する変動の状態 を示す，Qスイッチ発振YAGレーザーを用いた溝加工時に は, 同図に示すように同型の信号が繰り返し出力されてお り,またこの信号の繰り返されている時間間隔は, 加工条
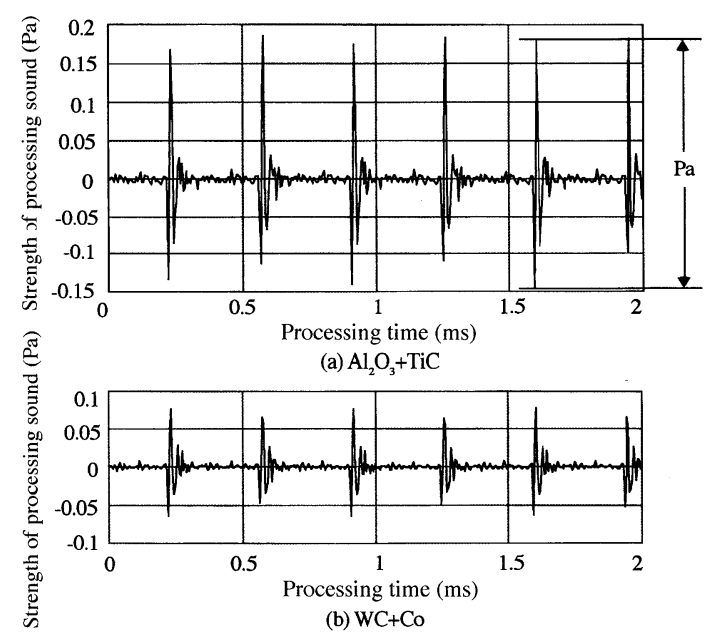

Laser energy: $1.40 \mathrm{~J} / \mathrm{s}$, Stage travel speed: $1 \mathrm{~mm} / \mathrm{s}$, Q-sw. frequency: $3 \mathrm{kHz}$

Fig.3 Distribution pattern of the strength of processing sound versus processing time. 
件として設定したQスイッチ周波数の逆数に等しくなるこ と, 㧍よび, 被加工材料が異なると個々の信号の振幅が異 なっていることなどから, 各々の波形はQスイッチ発振 YAGレーザー1パルスの照射に伴い発生した加工音に対応 すると考えることができる。本研究では, Qスイッチ発振 YAGレーザーの照射時に検出された信号の最大振幅を加 工音の強さ $(\mathrm{Pa})$ と定義した。

\section{2 加工溝断面積の測定}

Qスイッチ発振YAGレーザーを用いた溝加工において， 被加工材料上にレーザー光の焦点径を直径とする円を想 定したとき,その部分にQスイッチ発振YAGレーザーが照 射される回数は, ステージ移動速度を $v(\mathrm{~mm} / \mathrm{s})$, 焦点径を $d$ $(\mu \mathrm{m}), \mathrm{Q}$ スイッチ周波数を $q(\mathrm{kHz})$ とすれば, $(d \cdot q) / v$ で計 算される值で表すことができ,本研究ではこの回数の最大 值を最大照射数と定義している. 最大照射数を変化する ことにより,Fig.4に示すように加工される溝の断面積は異 なってくる. 本報では, 同図の溝断面の面積を計算して,特 定の加工条件に扔ける加工溝断面積と定義した。なお， Fig.4には被加工材料として選定した $\left(\mathrm{Al}_{2} \mathrm{O}_{3}+\mathrm{TiC}\right)$ 七ラ ミックおよび $(\mathrm{WC}+\mathrm{Co})$ 超硬合金について, $\mathrm{Q}$ スイッチ発振 YAGレーザーにより加工した溝断面の形状を示している. 同じ加工条件であっても超硬合金の断面積はセラミックス の場合に比較して非常に小さいのが特徴的である.

\section{3 加工溝断面積と加工音強さの関係}

Fig.5に, $\left(\mathrm{Al}_{2} \mathrm{O}_{3}+\mathrm{TiC}\right)$ セラミックおよび $(\mathrm{WC}+\mathrm{Co})$ 超硬 合金を被加工材料としたときの,最大照射数に対する加工 音の強さ㧍よび加工溝断面積の関係を示す. $\left(\mathrm{Al}_{2} \mathrm{O}_{3}+\mathrm{TiC}\right)$ セラミックを被加工材料とした場合, 加工溝断面積は最大 照射数の増加に対して約3000回までは急激に増加するが, それ以上最大照射数を増加しても緩やかな傾向で増加す

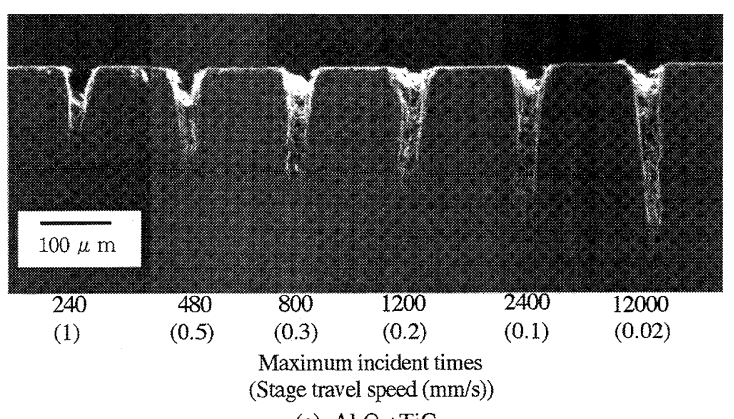

(a) $\mathrm{Al}_{2} \mathrm{O}_{3}+\mathrm{TiC}$

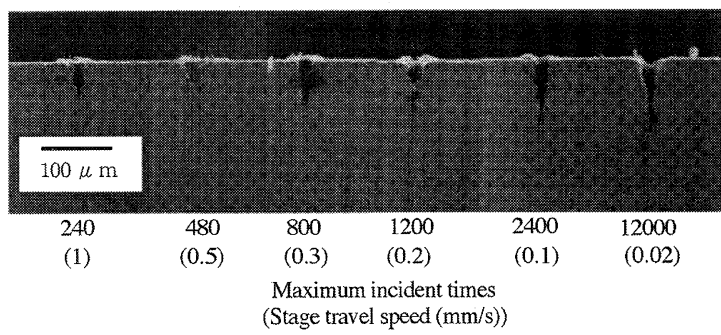

(b) $\mathrm{WC}+\mathrm{Co}$

Laser energy: $1.40 \mathrm{~J} / \mathrm{s}$, Initial width of groove: $80 \mu \mathrm{m}$, Stage travel speed: $0.01 \sim 1.5 \mathrm{~mm} / \mathrm{s}$, Q-sw. frequency: $3 \mathrm{kHz}$

Fig.4 SEM images of processed groove.

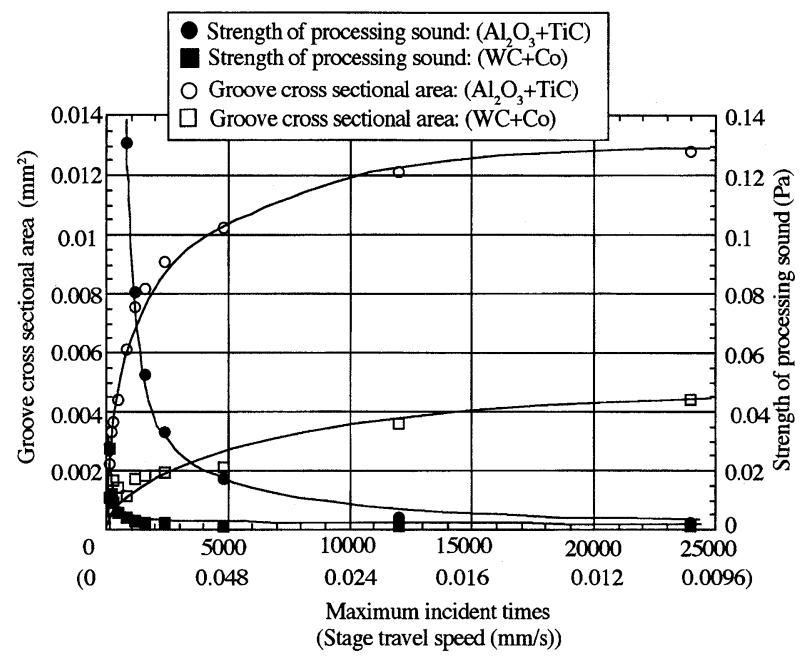

Laser energy: $1.40 \mathrm{~J} / \mathrm{s}$, Initial width of groove: $80 \mu \mathrm{m}$, Stage travel speed: $0.01 \sim 1.5 \mathrm{~mm} / \mathrm{s}$, Q-sw. frequency: $3 \mathrm{kHz}$

Fig.5 Strength of processing sound and groove cross sectional area versus maximum incident times of laser beam.

るだけである。その時に測定した加工音の強さは, 最大照 射数の増加に対して約 3000 回までは急激に減少, それ以上 の值になると緩やかに減少する傾向を示す。一方 $(\mathrm{WC}+$ $\mathrm{Co}$ ) 超硬合金の場合, 変化の傾向はセラミックの場合と同 様であるが, 加工溝断面積, 加工音強さの值ともセラミッ クに比較して小さな值となっている。この様に, 加工条件 は全く同じであっても, 被加工材料によりレーザー光の最 大照射数に対する加工溝断面積および発生する加工音の 強さが大きく異なる現象が存在することを実験的に明ら かにした。

\section{4. 考 察}

本研究の目的は, Qスイッチ発振YAGレーザーを用いた 溝加工において, レーザー光1パルスにより除去される加工 溝断面積と, その時に発生した加工音の強さとの関係を実 験的に明らかにすることである。すでに記述したように， 筆者等は外部回路てQスイッナユニットを制御して任意の 周波数のレーザー光を照射できる装置を製作し, $1 \mathrm{~Hz}$ の レーザー光を被加工材料に照射して, 1パルス当たりの加工 穴断面積とその時に発生した加工音に含まれる特定の周 波数の音圧レベルとの間に直線関係が存在することを明 らかにした12).

ただしこの実験においては,

1) 低速繰り返しQスイッチレーザーを用いて行った穴あけ 加工における加工穴断面積を算出するために, 穴の最も 深い位置が現われるまで\#1000ダイヤモンド砥石で研 削したが, 研削作業時の微妙なダイヤル調整により, 最 も深い穴の位置を観察することが必ずしも容易ではな く,算出した加工穴断面積に誤差を生じていた可能性が あること，

2) 実験の精度を高めることを目的として, 同一条件におけ る実験を何度も繰り返して実施するためには多くの時 間が必要であること, 
等から, 加工穴断面積と加工音の音圧レベルの関係流、亦 る程度の誤差が存在することを前提として, 幅を持ったけ 線で表現せざるを得なかった。このため本報告の実騃で は, Fig.4に示した溝断面形状から算出した加工溝断面積产 用いてQスイッチ発振YAGレーザー1パルスあたりの加 $\mathrm{E}$ 溝断面積を算出することを試みた。この方法を用いるこ とにより,同一条件で加工した時の1パルスにより加工され た複数の断面を容易に研削加工することにより求めるこ とができ,それらの平均值を用いればある加工条件におけ る断面積を既発表の論文 ${ }^{12)} に$ 抒いて用いた手法よりも正 確に算出することができる。しかし, Qスイッチ発振YAG レーザーを用いた場合でも, 1パルスのレーザー光による加 工溝断面積の変化が少ないことは低速繰り返しQスイッチ レーザーを用いた場合と同様なので, Fig.5に示した実験結 果㧍よび以下の方法を用いてQスイッチ発振YAGレーザー 1パルスあたりの加工溝断面積を算出した。

Qスイッチ発振YAGレーザーを用いた溝加工において, 最大照射数 $N$ の時の加工溝断面積を $V, N_{0}$ の時の加工量を $V_{0}$ とすれば, 最大照射数Nにおける1パルス当たりの加工溝断 面積 $V_{\mathrm{P}}$ は,

$$
V_{\mathrm{P}}=\left(V-V_{0}\right) /\left(N-N_{0}\right)_{\left(N>N_{0}\right)}
$$

の式を用いて求めることができる．Fig.5に示す曲線の何 箇所かにおいて $N$ および $N_{0}$ に対応する加工溝断面積の值を 選んで $V_{\mathrm{P}}$ を算出した。また加工音の強さは, $\mathrm{Q}$ スイッチ発 振YAGレーザーによる溝加工において最大照射数が $N$ の時 に発生した值を計測して用いた。

4.1 加工溝断面積と加工音の強さの関係におよぼす 加工条件の影響

Fig.6に, $\left(\mathrm{Al}_{2} \mathrm{O}_{3}+\mathrm{TiC}\right)$ セラミックを被加工材料とした場 合の, Qスイッチ発振YAGレーザー1パルスにより除去され た加工满断面積と, その時の加工音の強さの関係を示す. 同図においてパラメータはQスイッチ発振YAGレーザー1 パルスのエネルギーである。この值は供給したレーザー エネルギーおよびQスイッチ周波数の組み合わせで, 0.2 $0.62 \mathrm{~mJ} /$ パルスの範囲で変化させた，同図から両者は対数 グラフ上で直線関係を示すこと，掠よびQ久イッチ発振 YAGレーザー1パルスのエネルギーを変化させてもほぼ同 一直線で表わされることが理解できる。このことは,レー ザー加工条件である平均レーザー出力, $\mathrm{Q}$ スイッチ周波数 拉よびステージ移動速度が変化しても, 被加工材料が一定 ならば, Qスイッチ発振YAGレーザー1パルスが照射された 時に発生する加工音の強さを測定すれば, その時に除去さ れる加工溝断面積の大きさを実験的に求めることができ ることを示している.

4.2 加工溝断面積と加工音の強さの関係におよぼす 被加工材料の影響

加工溝断面積と加工音の強さの関係におよぼす被加工 材料の影響を実験的に明らかにするために選定した4種類 の被加工材料を, エネルギー分散形X線分光器 (EDS) を用 いて定性分析した結果をFig.7に示す。同図 (a)，(b)に示し

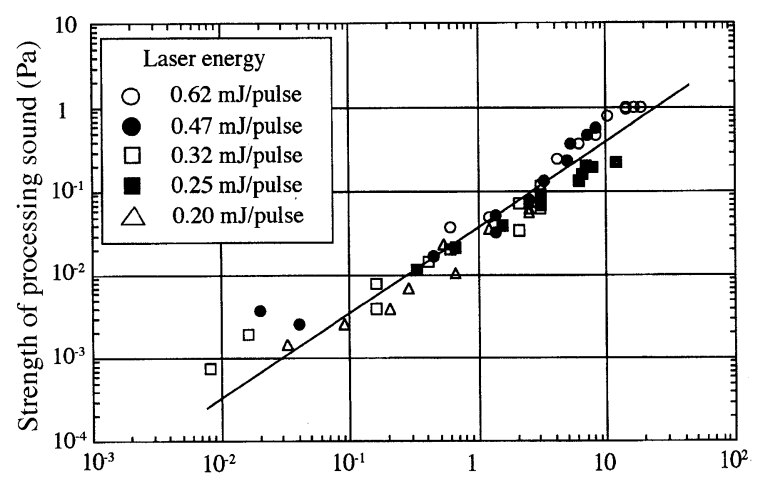

Groove cross sectional area per pulse ( $\mu \mathrm{m}^{2} /$ pulse $)$ Stage travel speed: $0.01 \sim 1.5 \mathrm{~mm} / \mathrm{s}$, Work material: $\mathrm{Al}_{2} \mathrm{O}_{3}+\mathrm{TiC}$

Fig.6 Relationship between groove cross sectional area per pulse and strength of processing sound.

た $\left(\mathrm{Al}_{2} \mathrm{O}_{3}+\mathrm{TiC}\right)$ 抢よび $\mathrm{Si}_{3} \mathrm{~N}_{4}$ セラミックでは主成分以外の 元素は検出されず,主に標記の成分のみで構成されている と思われる。一方 $(\mathrm{WC}+\mathrm{Co})$ および $(\mathrm{WC}+\mathrm{TiC}+\mathrm{TaC}+\mathrm{Co})$ 超硬合金は, 同図 (c), (d) に示すように標記元素以外に, 製 造工程で用いられる触媒である $\mathrm{Fe}$ あいはAI等が検出さ れているが, 主成分は炭化物を構成している金属元素とCo である。なお, 定性分析に用いた測定器の特性で, 酸素あ るいは窒素等の軽元素は検出できない. Fig.8は, 4 種類の 材料すべてを対象にして,レーザーエネルギー $1.40 \mathrm{~J} / \mathrm{s}, \mathrm{Q}$ 久 イッチ周波数 $3 \mathrm{kHz}$ 㧍よびステージ移動速度 $0.01 \sim 1.50$ $\mathrm{mm} / \mathrm{s}$ の条件で, Qスイッチ発振YAGレーザー1パルスによ
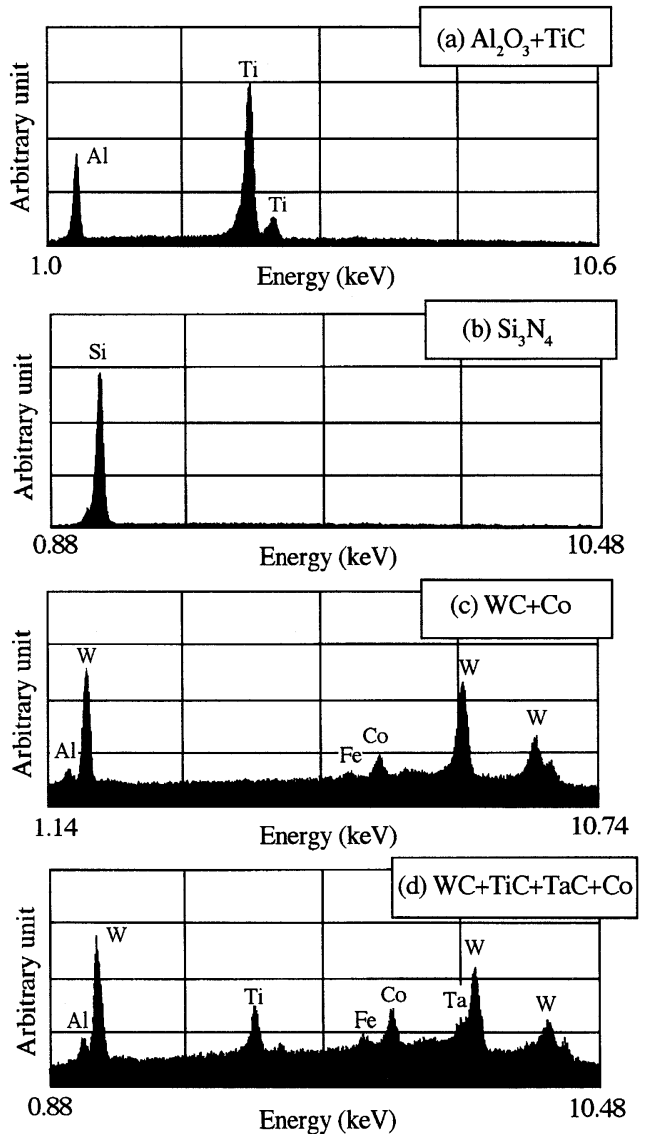

Fig.7 Qualitative analysis of work material with EDS. 
り除去される材料の加工溝断面積とそのときの加工音の 強さの関係を求め,同一のグラフにまとめた結果である. 1パルスのレーザー光により除去される材料の加工溝断面 積の大きさが同じ場合, 超硬合金に比較してセラミック材 料が除去されるときの加工音は大きな值を示している.

同図から理解できる特徽的な現象は, 2 種類のセラミック 材料㧍よび2種類の超硬合金の1パルス当たりの加工溝断 面積と加工音の強さの関係は各々両対数グラフ上で直線 で表すことができることである. Fig.9は最大照射数800の 条件で加工された溝加工の断面のSEM像であるが, (WC+ $\mathrm{Co}$ ) 超硬合金の場合 (同図 (b) 参照)レーザー光の影響を受 けたと考えられる溝は形成されているが, 実際には溝の内 部にレーザーエネルギーにより溶融した材料が再凝固し たと思われる部分が多く残存しており, 溝の一部しか被加 工材料から除去されていないことがわかる。これに対し て $\left(\mathrm{Al}_{2} \mathrm{O}_{3}+\mathrm{TiC}\right)$ セラミック材料の場合(同図 (a) 参照)には, 再凝固したと考えられる部分は超硬合金に比較すると少 なく,かなりの部分が除去されている. 即ち, 同じ大きさ の領域にレーザー光が影響をおよほしているとしても, 実 質的には $\left(\mathrm{Al}_{2} \mathrm{O}_{3}+\mathrm{TiC}\right)$ セラミックの場合が $(\mathrm{WC}+\mathrm{Co})$ 超 硬合金よりも多くの材料が除去されていることになり,こ の差が加工音の強さの差として影響していると考える.

\section{5. 結 論}

1パルスのレーザー光で除去される被加工材料の加工溝 断面積の大きさと加工音の強さとの関係を, $\mathrm{Q}$ スイッチ発 振YAGレーザーを用いた溝加工の結果を用いて明らかに し, 更にこの関倸に扔よぼす加工条件および被加工材料の 影響を実験的に明らかにすることを目的とし実施した研 究で得られた結論を, 以下に記述する。

1) Qスイッチ発振YAGレーザーを用いた溝加工において, $\left(\mathrm{Al}_{2} \mathrm{O}_{3}+\mathrm{TiC}\right)$ セラミックおよび $(\mathrm{WC}+\mathrm{Co})$ 超硬合金を 被加工材料とした場合, レーザー光の最大照射数に対す る加工音の強さ㧍よび加工溝断面積の関係を実験的に 求めた，その結果, 最大照射数が増加すると加工溝断面 積はある最大照射数までは急激に増加するが，それ以上 最大照射数を増加すると緩やかな増加傾向を示す。一

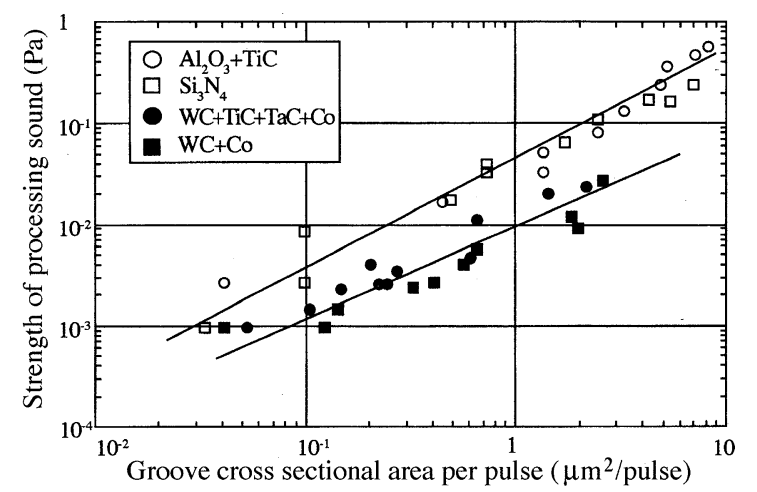

Laser energy: $1.40 \mathrm{~J} / \mathrm{s}$, Stage travel speed: $0.01 \sim 1.5 \mathrm{~mm} / \mathrm{s}$, Q-sw. frequency: $3 \mathrm{kHz}$

Fig.8 Relationship between strength of processing sound and groove cross sectional area per pulse.

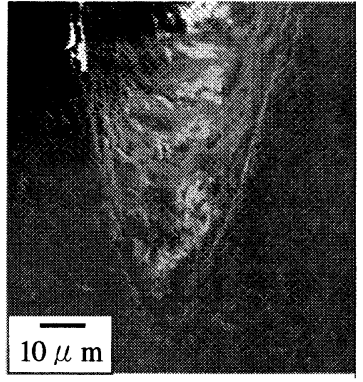

(a) $\mathrm{Al}_{2} \mathrm{O}_{3}+\mathrm{TiC}$

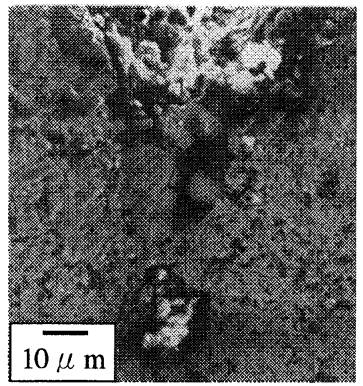

(b) $\mathrm{WC}+\mathrm{Co}$
Laser energy: $1.40 \mathrm{~J} / \mathrm{s}$, Q-sw. frequency: $3 \mathrm{kHz}$, Stage travel speed: $0.3 \mathrm{~mm} / \mathrm{s}$

Fig.9 SEM images of cross sections of processed groove.

方加工音の強さに関しては加工溝断面積とは逆の傾向 で減少する。 $(\mathrm{WC}+\mathrm{Co})$ 超硬合金の場合にも変化の傾向 は同様であるが, いずれの值とも $\left(\mathrm{Al}_{2} \mathrm{O}_{3}+\mathrm{TiC}\right)$ セラミッ クを被加工材料とした場合より小さな值となる。

2) Qスイッチ発振YAGレーザーの1パルス当たりのエネル ギーを, 平均レーザーエネルギーおよびQスイッチ周波 数の組み合わせにより変化させて実験を行い, 1 パルス 当たりの加工溝断面積の大きさとその時に発生した加 工音の強さの関係を求め,いずれの大きさのエネルギー を供給した場合にも, 両者は両対数グラフ上で1本の直 線で表すことができることを実験的に明らかにした。

3) Qスイッチ発振YAGレーザー1パルス当たりの加工溝断 面積の大きさと加工音の強さの間に存在する直線関係 は, $\left(\mathrm{Al}_{2} \mathrm{O}_{3}+\mathrm{TiC}\right)$ および $\mathrm{Si}_{3} \mathrm{~N}_{4}$ セラミックと $(\mathrm{WC}+\mathrm{Co})$ および $(\mathrm{WC}+\mathrm{TiC}+\mathrm{TaC}+\mathrm{Co})$ 超硬合金で傾向が異なる ことが実験的に明らかになった。この理由としては,材 料除去特性の違いが考えられる.

4) Qスイッチ発振YAGレーザー1パルスによる加工溝断面 積の大きさと加工音の強さの関係を, 低速繰り返しQス イッチレーザーを用いた実験の場合よりも精度を高く 表すことができることが明らかとなった。この結果, $\mathrm{Q}$ スイッチ発振YAGレーザー1パルスを照射したときに発 生する加工音の強さを測定すれば, その時除去される加 工溝断面積の大きさを求めることができることが明ら かとなった。

\section{参考文献}

1) G. V. Arbach, R. L. Melcher, and C. E. Scranton: IBM Tech. Disclosure Bull. 25 (1983) 5092.

2) C. E. Yeack, R. L. Melcher, and H. E. Klauser: Appl. Phys. Lett. 41 (1982) 1043.

3) T. Miyazaki, T. Uemura, and Y. Yamamoto: Ann. CIRP. 22 (1973) 67.

4) M. T. Brienza and A. J. DeMaria: Appl. Phys. Lett. 11 (1967) 44.

5) 宮崎 俊行, 田中 義弘：精密工学会誌 55 (1989) 508.

6）宮崎 俊行, 田中 義弘：精密工学会誌 55 (1989) 1421.

7) 宮崎 俊行, 德永 剛, 田中 義弘：精密工学会誌 55 (1989) 2069.

8) W. W. Duley and Y. L. Mao: Appl. Phys. 27 (1994) 1379

9) R. D. Rawlings and W. M. Steen: Optics and Laser in Engineering 2 (1981) 173.

10) P. Sheng and G. Chryssolouris: J. Mater. Process. Technol. 43 (1994) 145.

11）栗田 恒雄, 大野 幸彦, 森田 昇：レーザー研究 25 (1997) 88.

12）栗田 恒雄, 大野幸彦, 森田昇：レーザー研究 26 (1998) 754. 